\title{
Євген МИЛОВАНОВ
}

\section{ПРИНЦИПИ ЗДОРОВ'Я ЯК ВАГОМИЙ ФАКТОР ВПЛИВУ НА РОЗВИТОК ОРГАНІЧНОГО СІЛЬСЬКОГО ГОСПОДАРСТВА УКРАЇНИ}

Здійснено порівняльний аналіз органічного та конвенційного агровиробництва $з$ урахуванням параметрів, важливих для здоров'я людини та висвітлено потенційний вплив практики органічного менеджменту на розвиток збалансованих харчових систем. Зазначено, що споживання органічних продуктів може знизити ризик розвитку алергічних захворювань, надлишкової ваги та ожиріння, але поки що залишається потреба у більш переконливих доказах, оскільки споживачі органічних продуктів мають загалом більш здоровий спосіб життя. Розглянуто наукові експерименти на тваринах, які свідчать про те, що корми, одержані від органічного та конвенційного виробництва, по-різномувпливають на ріст і розвиток. Зауважено, що в органічному сільському господарстві використання синтетичних пестицидів заборонено, тоді як залишки у конвенційних фруктах і овочах є основним джерелом впливу пестицидів на людину. Подано динаміку використання засобів захисту рослин вітчизняними господарствами та наведена порівняльна характеристика кількості внесення пестицидів в Україні та світі протягом останніх років. Наголошено, що епідеміологічні дослідження повідомляють про несприятливий вплив пестицидів на когнітивний розвиток дітей та канцерогенний ризик для здоров'я населення, але ці дані досі не застосовувалися в офіційних оцінках ризику окремих пестицидів. Зазначено, що розвиток органічного сільського господарства також знижує професійний вплив пестицидів на сільськогосподарських працівників та жителів сільської місцевості. Акцентовано увагу на занепокоєнні наукових кіл щодо поширення використання антибіотиків при конвенційному вирощуванні тварин як ключового фрактору стійкості до антибіотиків у населення, на противагу органічному тваринництву, де застосування антибіотиків дуже обмежене. Зроблено висновок, що виробництво органічних харчових продуктів має кілька задокументованих і потенційних переваг для організму людини, тому швидше за все сприятиме здоров'ю населення. Подано рекомендації щодо майбутніх напрямів досліджень, для подальшої конкретизації даного потенціалу для забезпечення здоров'я населення, тварин, землі та всього навколишнього середовища. На основі висновку щодо потенційного позитивного впливу на здоров'я від виробництва та вживання органічних харчових продуктів.

(C) Свген Милованов, 2019. 
Ключові слова: органічне сільське господарство, принцип здоров'я, безпечність харчових продуктів, залишки пестицидів, конвенційне агровиробництво.

JEL:Q100

Постановка проблеми. Важливою основою сучасного органічного сільського господарства є дотримання загальноприйнятих принципів, серед яких особливо актуальним на нинішньому етапі розвитку вітчизняної економіки та суспільства $€$ принцип здоров'я.

Довгострокова мета розвитку сталих продовольчих систем вважається пріоритетом багатьох урядів світу, в т. ч. і в Україні, та міжурядових організацій європейського та світового рівнів. Різні системи управління сільським господарством тісно пов'язані зі сталістю продовольчих систем, оскільки вони можуть впливати на здоров'я людини, а також на добробут тварин, продовольчу безпеку та екологічну стійкість. Але органічні системи господарювання базуються на методах, що апріорі виключають використання шкідливих синтетичних речовин в агровиробництві, спрямовані на турботу щодо тварин та навколишнього середовища, орієнтуються на якість та безпечність харчової продукції і саме тому повинні бути пріоритетними для вітчизняної економіки.

Зважаючи на це, методи виробництва харчових продуктів не завжди легко класифікувати та розмежувати. Ця складність випливає не лише з кількості та різноманітних форм традиційних і органічних систем сільського господарства, але також в результаті перекриття цих систем. Тому питання позитивного впливу органічного сільського господарства на здоров'я населення потребує подальших наукових пошуків та доказів, які спирались би на конкретні факти та довготермінові дослідження.

Аналіз останніх досліджень і публікацій. Зв'язок між системою органічного сільського господарства та здоров'ям населення був об'єктом досліджень як зарубіжних, так і вітчизняних науковців та практиків, серед яких І. В. Кошкалда [5], Т. 3. Бубела, О. В. Воробець [2], К. Дангур [11], М. Айзінзер-Ватцл [12], Дж. Форман [14], М. Хубер [15], Е. Кессе-Гайот [19], С. Смит-Спанглер [22], Х. Тор'юсен [25], А. Велиміров [26] та багато ін. Зважаючи на наукову значущість робіт вищенаведених дослідників, зауважимо, що надзвичайно актуальними залишаються дослідження, спрямовані на наукове обґрунтування та оцінку впливу органіки на стан здоров'я населення.

Метою статті $€$ теоретико-методичне обґрунтування значущості органічного сільського господарства в контексті забезпечення принципу здоров'я на сучасному етапі розвитку вітчизняної аграрної галузі та національної економіки загалом.

Виклад основного матеріалу дослідження. Нині все більша частина суспільства усвідомлює важливість здорового харчування для самопочуття, здоров'я, так і для загального добробуту. Оброблені продукти з високим вмістом насичених жирів, цукру та натрію, а також з низьким вмістом необхідних поживних речовин не лише несуть відповідальність за проблеми з надмірною вагою тіла, але доведено, що вони є головними фракторами для низки проблем зі здоров'ям, включаючи діабет, високий кров'яний тиск і хвороби серця. Щоб погіршити ситуацію, існують також різні штучні консерванти, підсилювачі смаку та ряд інших хімічних речовин із сумнівним 
впливом на здоров'я. 3 іншого боку, що особливо важливо, на наш погляд, сучасні неперероблені продукти не настільки здорові, як здається, тому що більшість з них вирощується конвенційно, що означає масове використання хімічно синтезованих пестицидів і мінеральних добрив, ГМО, антибіотиків, гормонів росту, підсилювачів смаку та інших штучних добавок.

Принцип здоров'я $€$ основоположним в органічних практиках господарювання, оскільки спрямований на надзвичайно важливу соціальну ціль - органіку, що зможе забезпечити організм людини якісним та безпечним харчуванням, а також разом із цим підтримувати та поліпшувати здоров'я ґрунту, рослин, тварин та планети як єдиного й неподільного цілого.

Розуміння важливості даного принципу значною мірою сприяло активному збільшенню попиту на органічну продукцію в усьому світі і в Україні зокрема.

Світовий органічний ринок вже багато років поспіль демонструє позитивну тенденцію, а саме: зростає попит споживачів на органічну продукцію, все більше господарств практикують органічні методи агровиробництва, площі сертифікованих органічних угідь щорічно збільшуються і вже 181 країна звітує про органічну сільськогосподарську діяльність. Зокрема, світовий ринок органічних харчових продуктів перетнув у 2017 р. межу 92 млрд. євро, що на 106,8\% більше, ніж у 2010 р.

Споживання органічних продуктів у світі, млн. євро

\begin{tabular}{|c|c|c|c|c|c|c|c|c|}
\hline Рік & 2010 & 2011 & 2012 & 2013 & 2014 & 2015 & 2016 & 2017 \\
\hline Млн. євро & 44,522 & 47,805 & 51,100 & 56,370 & 62,816 & 75,709 & 84,698 & 92,074 \\
\hline
\end{tabular}

Джерело: розроблено на основі [27].

При цьому провідним ринком споживання органічних продуктів є Сполучені Штати Америки з 40,01 млрд. євро, за ними йдуть Німеччина (10,04 млрд. євро), Франція (7,92 млрд. євро), Китай (7,64 млрд. євро) та з суттєвим відривом Італія (3,14 млрд. євро). У 2017 р. на більшості основних ринків і далі спостерігалися двозначні темпи зростання, при цьому китайський органічний ринок зріс найбільше - на 29,6\%. Найвищі витрати на органік на душу населення були у Швейцарії (288 євро) та Данії (278 євро). Данія також мала і найбільшу частку органічного ринку (13,3\% від загального продовольчого ринку). Країнами з найбільшою часткою органічних земель у загальній площі сільськогосподарських угідь були Ліхтенштейн $(37,9 \%)$, Самоа $(37,6 \%)$, Австрія $(24,0 \%)$ та Естонія (20,5\%). У чотирнадцяти країнах $10 \%$ і більше від усіх сільськогосподарських земель є органічними [27].

Стан розвитку вітчизняного органічного сільського господарства теж характеризується зростаючою динамікою. Незважаючи на труднощі економічного, інституційного та військово-політичного характеру, органічний сектор аграрної галузі в Україні постійно нарощує темпи виробництва та реалізації. Останні роки продемонстрували доволі позитивні зміни: збільшилася площа під органічним виробництвом (з 240 тис. га у 2004 р. до 420 тис. га у 2017 р. - на 75\%), зросла кількість сертифікованих органічних господарств (з 70 у 2004 р. до 375 у 2017 р. - у 
5,4 рази), значно виріс обсяг органічного ринку (з 0,1 млн. євро у 2004 р. до 29,4 млн. євро у 2017 р. - у 294 рази). За попередніми оцінками Федерації органічного руху України, у 2018 р. споживання органічних продуктів в Україні знову зросло, сягнувши 33,0 млн. євро. Експорт вітчизняної сертифікованої органічної сільськогосподарської та харчової продукції у 2017 р. склав 99 млн. євро (порівняно з 65 млн. євро у 2016 р.) [6].

Наведена позитивна статистика свідчить про еволюцію усвідомленого вибору більш інформованими споживачами, які переймаються питаннями здоров'я власного та своїх близьких, здорової харчової органічної продукції, переваги якої вже багато років доводить світова наукова спільнота.

Загалом органічне агровиробництво ґрунтується на принципах, які були прийняті у 2005 р. на Міжнародному Конгресі в Аделаїді (Австралія) Міжнародною Федерацією органічного сільськогосподарського руху (IFOAM), за участі Федерації органічного руху України. Ці принципи лягли в основу системи інституціоналізації та правового забезпечення розвитку органічного сільського господарства багатьох країн світу [8, c. 79].

Серед згаданих чотирьох принципів не варто шукати пріоритетні, оскільки вони рівною мірою є визначальними та взаємодоповнюючими (рис. 1).

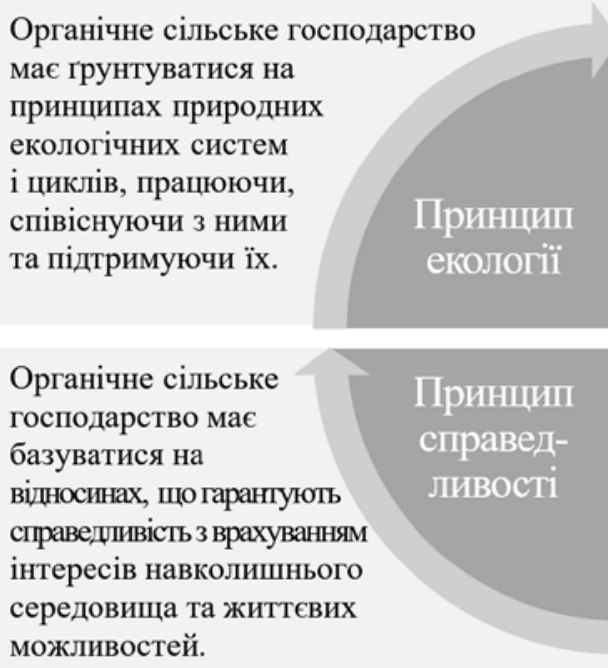

Органічне сільське господарство має грунтуватися на принципах природних екологічних систем і циклів, працюючи, співіснуючи з ними Принцип екології

Принцип турботи

Управління органічним сільським господарством повинне мати попереджувальний і відповідальний характер для захисту здоров'я й добробугу як нинішніх і прийдешніх поколінь, так і довкілля.

$\begin{array}{lc}\text { Органічне сільське } & \text { Принщй } \\ \text { господарство має } & \text { справед- } \\ \text { базуватися на } & \text { ЛИвості } \\ \text { відносинах, що гарантують } & \\ \text { справедливість з врахуванням } & \\ \text { інтересів навколишнього } \\ \text { середовища та життєвих } \\ \text { можливостей. }\end{array}$

\section{Рис. 1. Базові принципи органічного сільського господарства згідно IFOAM - Organic International}

Джерело: [8, с. 80].

Сучасні дослідження щодо ролі споживання органічних харчових продуктів для здоров'я людини $[11 ; 14 ; 22] \epsilon$ дефріцитними у порівнянні з іншими темами здорового харчування. Зокрема, бракує довгострокових системних досліджень, спрямованих на виявлення потенційних зв'язків між споживанням органічних продуктів і здоров'ям, що пов'язано насамперед з високими витратами на такі дослідження. Вибіркові 
дослідження $€$ реальним способом вивчення таких взаємозв'язків, хоча оцінка відповідності є складним завданням.

У роботі ми використовуємо термін «конвенційне сільське господарство» як домінуючий тип інтенсивного агровиробництва, зазвичай з високим рівнем використання синтетичних пестицидів і мінеральних добрив, а також високою часткою конвенційно вироблених кормів для тварин. На противагу конвенційному, «органічне сільське господарство» відповідає регулюванню Євросоюзу, США або аналогічним стандартам для органічного агровиробництва, включаючи використання дозволених органічних добрив, таких як компост, зелені добрива, дотримання сівозмін, здійснення екосистемних послугі нехімічних заходів для попередження та боротьби зі шкідниками, забезпечення «зеленого конвеєру» у тваринництві тощо.

У грудні 2016 р. Служба європейських парламентських досліджень (EPRS) оприлюднила досить докладний та комплексний звіт [16] щодо впливу органічного сільського господарства та органічного харчування на здоров'я людини. Цей документ $\epsilon$ оглядом раніше опублікованих наукових досліджень, які оцінювали аспекти впливу органічних продуктів на здоров'я людини. Хоча наявні дані дещо обмежені, результати показують, що існують вагомі корисні асоціації між органічним харчуванням та здоров'ям населення. Опубліковані дані переконливо свідчать про те, що:

1. Більше споживання органічних продуктів може бути пов'язане з меншим ризиком алергій у дітей.

2. Люди, які їдять більше органічних продуктів, як правило, дотримуються здоровішої дієти з більш високим споживанням фруктів, овочів і цільного зерна та меншим споживанням м'яса, з режимом харчування, який пов'язаний 3 меншим ризиком хронічних захворювань, таких як цукровий діабет та серцево-судинні хвороби.

3. Дорослі, які частіше харчуються органічними продуктами, рідше мають надлишкову вагу або ожиріння.

4. Органічне сільське господарство спирається на біорозкладні пестициди, які швидко розкладаються і є нетоксичними або лише мінімально токсичними для людей, на противагу штучним хімічним пестицидам, таким як органофосфати (які, незважаючи на назву, не $€$ частиною системи органічного менеджменту). Епідеміологічні дослідження чітко показали, що вміст органофосфратних інсектицидів у харчових продуктах негативно впливає на когнітивний розвиток дітей, а існуючі дослідження підтверджують теорію, що зниження впливу залишків пестицидів позитивно впливає на людський організм, особливо вагітних жінок і дітей.

5. Органічні ферми, як правило, застосовують більш низькі рівні внесення добрив і покладаються на сталі системи менеджменту, які уповільнюють або запобігають розповсюдженню хімікатів, тому вони рідше забруднюють земну поверхню або підземні води.

6. Фермери в органічних практиках, як правило, використовують продукти життєдіяльності тварин, а не мінеральні хімічно-синтезовані добрива, а також підтримують більш високий рівень органічної речовини у ґрунті. Ці відмінності призводять, зокрема, до зниження вмісту кадмію у зібраному врожаї.

7. Кілька досліджень на тваринах показують, що споживання органічно вирощених кормів замість конвенційних може підтримувати здорову імунну систему наступних 
поколінь, але результати, виявлені у дослідженнях на тваринах, не завжди виявляються однаковими і для людей.

8. Органічні фермери частіше практикують відкритий випас худоби, ніж конвенційні фермери, а молоко та інші молочні продукти від тварин, що харчуються травою 3 луків, мають вищі рівні омега-3 жирних кислот та меншу кількість омега-6 жирних кислот, ніж ті, що від тварин, яких вигодовують неорганічним зерном.

9. Органічні практики вирощування худоби не передбачають застосування антибіотиків, оскільки вони можуть створювати стійкі до антибіотиків штами бактерій хвороб людини. Сильні антибіотики є серйозною проблемою системи охорони здоров'я для всіх, незалежно від того, яку систему харчування вони обирають, оскільки стійкі до антибіотиків мікроорганізми можуть переноситися повітрям на великі відстані, а також бути передані працівниками медичних закладів та громаді [16].

У вибіркових дослідженнях особлива проблема полягає у тому, що споживачі, які регулярно купують органічні харчові продукти, схильні вибирати більше овочів, фруктів, цільно-зернових продуктів і менше м'яса, а також мають загальну здорову дієтичну систему харчування [19; 25]. Кожна із цих дієт пов'язана зі зниженням ризику смертності або захворюваності у зв'язку з певними хронічними хворобами [9; 10]. Споживачі, які регулярно купують органічні продукти харчування, також $€$ більш фрізично активними і рідше палять [12; 19]. Щодо дитячих захворювань, то декілька досліджень повідомляли про меншу поширеність алергії та/або атопічного дерматиту у сім'ях, де харчування базується на органіку [13; 24]. Отже, у більшості цих досліджень органічне споживання їжі $є$ частиною більш здорового способу життя і тому пов'язане з іншими факторами життєдіяльності.

Беручи до уваги труднощі проведення довгострокових досліджень систем харчування людей, дослідження на тваринах пропонують певний потенціал вивчення довгострокових наслідків для якості харчових продуктів. Дослідження в цій галузі почалися майже 100 років тому. Огляд великого числа досліджень [26] привів до висновку, що позитивні ефекти органічних кормів на здоров'я тварин $є$ можливими, але необхідні подальші дослідження для підтвердження цих висновків.

В одному з досліджень кури, яких годували конвенційно вирощеними кормами, демонстрували більш високу швидкість росту. Однак імунітет курей, які отримували органічні корми, відновлювався швидше [15]. Це зміцнення імунної системи трактувалось як ознака кращого здоров'я.

Загалом дослідження на тваринах показали, що система рослинництва впливає на певні аспекти життя клітин, імунної системи та загального росту та розвитку. Проте безпосереднє значення цих знахідок для здоров'я людини вчені світу ще вивчають. 3 іншого боку, ці дослідження можуть забезпечити вірогідність потенційного впливу конвенційних та органічних продуктів на здоров'я людей.

В Україні подібні дослідження зв'язку органічного харчування із показниками здоров'я ще практично відсутні. Це, зокрема, пов'язано з низьким рівнем фінансування подібних дослідних проектів та несистемністю вживання органічних продуктів у раціоні українських сімей. Тим не менш, їх важливість $є$ очевидною та все більш актуальною на фроні збільшення кількості онкологічних та інших тяжких захворювань в Україні. 
Вважаємо за доцільне поглянути на досліджувану проблематику з точки зору методологічних особливостей органічного агровиробництва на противагу конвенційному.

Захист рослин у конвенційному сільському господарстві значною мірою залежить від використання синтетичних пестицидів. І, навпаки, органічне агровиробництво здебільшого спирається на запобігання та біологічні засоби захисту рослин, науковообґрунтовані сівозміни, стійкі районовані сорти, біологічний контроль з використанням природних ворогів та інші заходи.

Однією 3 головних переваг виробництва органічних продуктів харчування $€$ заборона використання синтетичних пестицидів, що дозволяє забезпечити низький рівень залишків у харчових продуктах і, таким чином, до зниження впливу пестицидів на споживачів.

Група з семи американських вчених нещодавно оприлюднила результати досліджень пацієнтів, у яких після початку харчування виключно органічною їжею менше, ніж через тиждень рівень залишків пестицидів у сечі знизився більш ніж на $60 \%$ у порівнянні з тим, який був на момент початку експерименту. Вчені спостерігали значне зниження в організмах експериментальної групи людей рівня метаболітів тринадцяти пестицидів і вихідних сполук, що представляють перелік із неонікотиноїдів, піретроїдних інсектицидів і гербіцидів 2,4-D після введення органічної дієти. Найбільші зміни спостерігалися щодо вмісту клотіанідину, метаболітів малатіону і хлорпир-ифосу. Цей звіт ґрунтувався на попередніх дослідженнях, які оцінювали вплив речовин, які до теперішнього часу не досліджувалися серед дітей і дорослих. Вчені продовжують додаткові дослідження для ліпшого розуміння впливу неонікотиноїдів, які сьогодні $€$ найпоширенішим класом інсектицидів у всьому світі [17, с. 568].

Зауважимо, що не лише уряди Німеччини, Франції, Данії та інших розвинених країн світу піклуються про здоров'я населення та навколишнє середовище, але й країни, що розвиваються.

Зокрема, президенти Шрі-Ланки Махінда Раджапаксе (у 2014 р.) та Майтріпала Сірісена (у 2015 р.) під впливом громадськості, занепокоєної зростанням тяжких захворювань серед фермерів, піднімали питання щодо необхідності заборони використання пестицидів, що містять гліфосат, у своїй країні [23].

У лютому 2019 р. уряд В'єтнаму офріційно оголосив про негайну заборону використання хімічних засобів, які містять активний компонент хлорпірифос-етил і фріпроніл. Це - перша країна в Південно-Східній Азії, яка офріційно заборонила ці хімічні препарати. За даними Міністерства сільського господарства В'єтнаму близько 35004000 т хлорпірифосу та фіпронілу використовувалося щороку у країні. Нещодавня доповідь PANAP (некомерційна організація, що виступає проти використання пестицидів) оприлюднила факти широкого використання у В'єтнамі дуже небезпечних пестицидів, включаючи хлорпірифос та фріпроніл. Ці пестициди використовувалися за невідповідних умов, таких як відсутність засобів індивідуального захисту та уразливості до випадкових розливів, що призводило до неприйнятних негативних наслідків для здоров'я. Жінки були найбільш вразливими та у них виявили більшість симптомів отруєння пестицидами. Заборона на використання хлорпірифосу та фіпронілу, безсумнівно, захистить багатьох в'єтнамських фермерів, жінок, дітей та споживачів від згубного впливу цих двох небезпечних пестицидів. Раніше, в 2017 р., у B'єтнамі були заборонені небезпечні гербіциди паракват і 2,4-D. 
Нині пестициди є невід'ємною частиною конвенційних технологій виробництва сільськогосподарської продукції по всьому світу. Для того, щоб зрозуміти небезпеку пестицидів для здоров'я людини, варто згадати дослідження міжнародної наукової спільноти, пов'язані з гліфосатом, який є активним компонентом найбільш популярного у світі пестициду, якого щороку у всьому світі продається на десятки мільярдів доларів.

У 2015 р. Міжнародне агентство з вивчення раку (IARC) Всесвітньої організації з охорони здоров'я оголосило, що гліфосат $€$ ймовірним канцерогеном. Оцінка Ґрунтувалася на «обмежених» доказах щодо захворювань на рак у людей (реальний вплив, що фрактично відбувався) і «достатніх» доказах раку у досліджуваних тварин. Вчені IARC також прийшли до висновку, що існують «вагомі» докази генотоксичності як «чистого» гліфосату, так і його складників [18].

Для того, щоб зробити подібні висновки, IARC розглянуло близько 1000 досліджень. Деякі дослідження вивчали людей, які піддавалися впливу на роботі, наприклад, фермери. Інші були експериментальними дослідженнями щодо ракових та ракозалежних ефектів в експериментальних умовах.

Оцінка IARC ґрунтується на системному огляді та консолідації всіх відкритих та відповідних досліджень незалежними експертами, вільними від упередження. Вона відповідає суворим науковим критеріям, а система класифікації визнається і використовується як довідник в усьому світі. Це доводить, що оцінки IARC базуються на незалежному науковому огляді та суворих критеріях та процедурах.

Гліфосат активно використовується у сільському господарстві і нашої країни. Він користується великою популярністю як у вітчизняних фермерів, так і у великих агрохолдингах. Достовірно відомо, що даний гербіцид використовується по всій території України, а його концентрація часто перевищує гранично допустимі норми [1].

В Україні агропідприємства використовують пестициди (переважно хімічносинтезовані) для боротьби з хворобами, бур'янами, комахами, гризунами тощо. Динаміка використання засобів захисту рослин вітчизняними господарствами наведена на рис. 2.

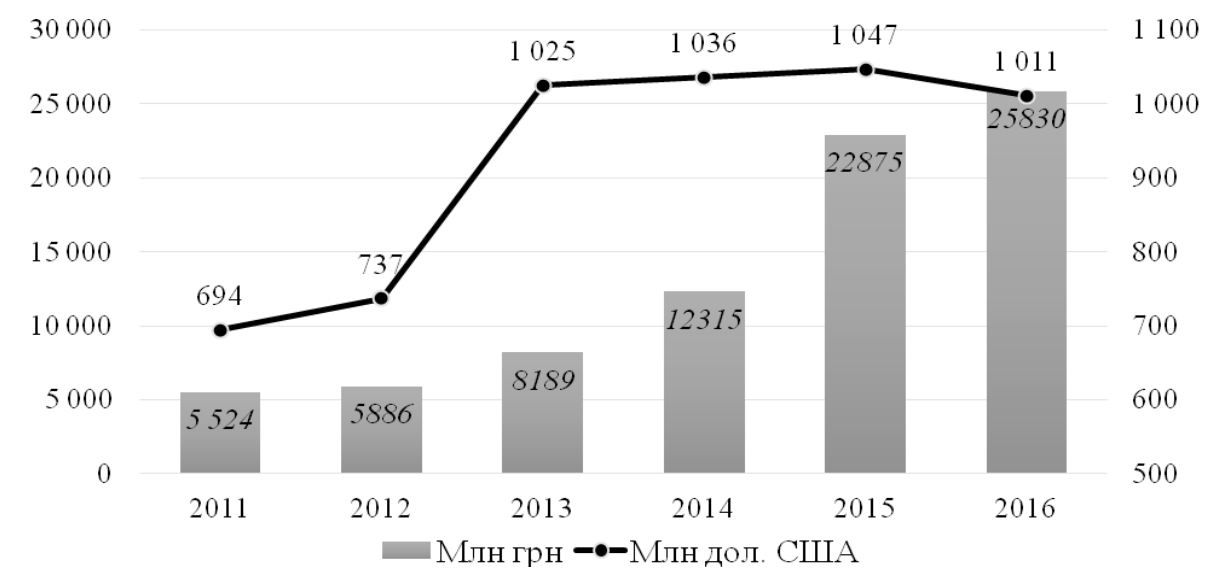

Рис. 2. Використання продукції захисту рослин, гербіцидів, інсектицидів, пестицидів вітчизняними агропідприємствами у 2011-2016 рр. Джерело: розроблено на основі [7]. 
Як бачимо з наведених даних, сільськогосподарські підприємства України використовували значно більше засобів захисту рослин у 2016 р. у порівнянні з 2011 р. Так, у розрахунку на національну валюту відбулося збільшення витрат на закупівлю 33Р майже вп'ятеро (на 20306 млн. грн.). Зважаючи на значні коливання курсу валют у нашій країні протягом аналізованого періоду, у розрахунку на долари США також відбулося помітне зростання даної статті витрат у вітчизняному агровиробництві - на $45 \%$ або 317 млн. дол. США.

На наступному етапі дослідження наведемо порівняльну характеристику динаміки норм внесення пестицидів у ґрунт в Україні та світі (рис. 3).

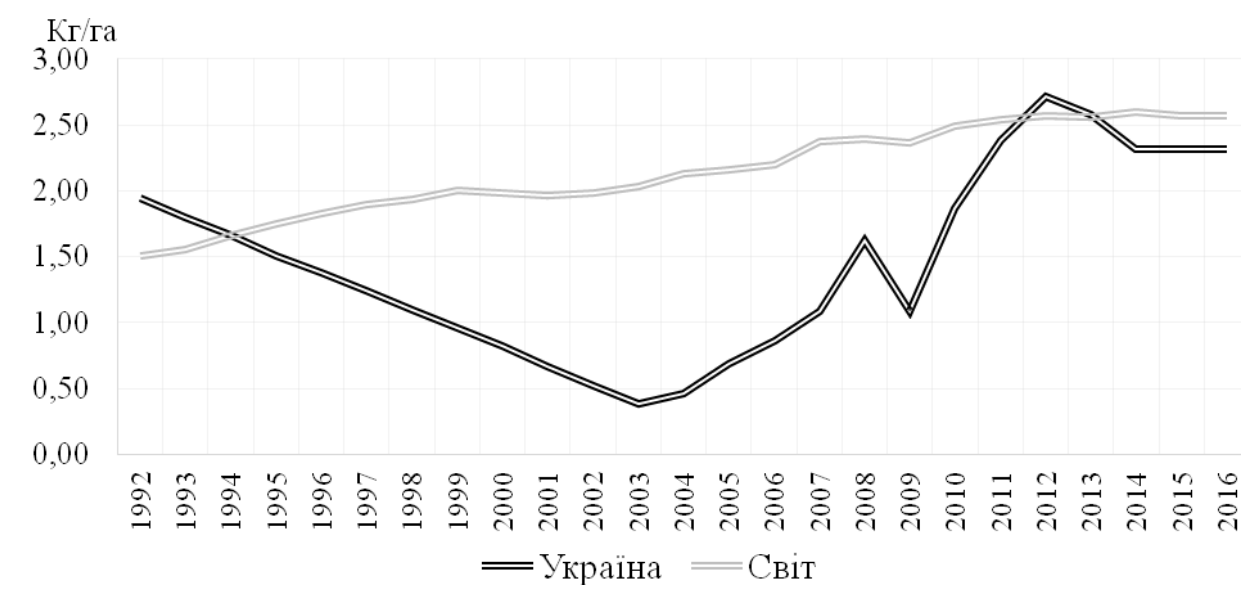

Рис. 3. Середні норми внесення пестицидів в Україні та світі у 1992-2016 рр.

Джерело: розроблено на основі [21].

Тобто в Україні, починаючи з 2003 р., спостерігається загальна тенденція до нарощення обсягів внесення агрохімікатів у ґрунт, залишки яких неодмінно тривалий час залишаються у навколишньому середовищі, їжі та організмах.

За даними, які знаходяться у відкритому доступі на сайті Мінприроди, впродовж 2016-2017 рр. в Україні зареєстровано 1092 дозволених до використання пестицидів та агрохімікатів, у т. ч. 298 пестицидів I і II класів - надзвичайно небезпечні. Відповідно до пункту 2.2. Державних санітарних правил (ДСП) 8.8.1.2.002-98 «Гігієнічна класифікація пестицидів за ступенем небезпечності» практичне застосування, тобто внесення підприємствами пестицидів I та II класів небезпечності здійснюється лише за умови постійного контролю санітарно-епідеміологічної служби. В результаті реорганізації СЕС повноваження контролю за дотриманням санітарного законодавства передані Державній службі України з питань безпечності харчових продуктів та захисту споживачів (Держпродспоживслужба). Контроль за жодним з пестицидів у воді, повітрі, ґрунтах, які саме пестициди використовують агропідприємства та в якій кількості, чи законно вони ввезені в Україну та чи не використовуються заборонені до використання в Україні або протерміновані, жодним державним органом на сьогодні фактично не здійснюється [1]. 
Природа токсичності пестицидів різноманітна - це може бути канцерогенний або мутагенний ефект, дія на дихальну, ендокринну, імунну, нервову системи. Головне значення тут відіграють два фрактори: те, що всі синтетичні пестициди - речовини, чужі живій природі та недоступні метаболічному розкладу і те, що практично всі вони здатні до біоакумуляції, тобто накопичуються в живих організмах в більших концентраціях, ніж в навколишньому середовищі.

Восени 2017 р. фрранцузький уряд заборонив до 2022 р. використання вищезгаданого гліфосату. Окрім цього, на державному рівні там планують провести повне дослідження ринку гербіцидів, що використовуються французькими фермерами. Раніше подібну заборону схвалили й у Німеччині [1].

Окремі пестициди не відчуваються на смак і запах, проте залишки їх містяться в овочах, фруктах і зелені, у повітрі, воді, ґрунтах. Кожен громадянин України, не зважаючи на соціальний статус і статки, може зазнати негативного впливу від пестицидів. Наукові дослідження показують, що пестициди здатні поширюватися у довкіллі на тисячі кілометрів, вони передаються з молоком матері до дітей, вони виявлені у жирових тканинах навіть пінгвінів. Тому для пестицидів немає жодних бар'єрів і кордонів, і проблема їхнього негативного впливу стосується кожного.

Отже, людина, у випадку накопичення пестицидів в організмі, схильна до загрози різного роду захворювань, у т.ч. онкологічних (про що свідчать дослідження IARC). В Україні, зважаючи на вищесказане, практично відсутній контроль використання пестицидів і, тому ймовірність впливу надмірного використання штучних засобів захисту рослин на здоров'я населення нашої країни вважаємо досить високою.

Для подальшого аналізу розглянемо динаміку онкологічних захворювань в Україні:

Осіб์

170000

$160000 \quad$\begin{tabular}{l}
$158595 \quad 156567$ \\
\hline
\end{tabular}

150000

$\begin{array}{llll}140000 & 134104 & 134330 & 135451\end{array}$

130000

120000

$1995 \quad 2000 \quad 2005 \quad 2010 \quad 2015 \quad 2016 \quad 2017$

Рис. 4. Динаміка захворювання населення на злоякісні новоутворення Джерело: розроблено на основі [4]. 
Отже, наведені дані дають можливість зробити висновок про зростаючу тенденцію кількості хворих з уперше в житті встановленим діагнозом на злоякісні новоутворення в Україні за останні 3 роки. 32015 по 2017 рр. кількість захворювань населення збільшилась на 1\% (1347 осіб). Відображене на рис. 2 падіння кількості хворих у 2015 р. пояснюється військовою агресією Росії проти України, в результаті чого статистика тимчасово окупованих територій стала недоступною.

Варто зауважити, що формування достовірних доказів зв'язку між кількістю захворювань на важкі хвороби та використанням пестицидів у сільському господарстві потребує глибоких, систематичних та довготермінових досліджень із високим рівнем фінансування. Але оцінка компетентних міжнародних організацій, фактичні статистичні дані та здоровий глузд дають можливість зробити висновок про високу ймовірність зв'язку та залежності між використанням синтетичних хімічних речовин у конвенційному сільському господарстві та здоров'ям людей.

Деякі критики стверджують, що ще недостатньо доказів того, що органічні продукти харчування є більш здоровими або безпечнішими, ніж звичайні (конвенційні), однак методи органічного сільського господарства говорять самі за себе. Основною ідеєю виробництва органічних продуктів $€$ уникнення всіх неорганічних методів землеробства, що означає, що використання хімічно-синтезованих пестицидів, добрив, антибіотиків, гормонів росту та подібних речей суворо регламентовано. Натомість органічні виробники використовують всі природні методи землеробства, які включають, зокрема, сівозміни, компостування, мульчування, біологічні методи захисту, стимулювання біорізноманіття тощо. В результаті, органічні продукти фактично не представляють ризику залишків пестицидів, а також присутності інших потенційно шкідливих хімічних речовин.

Отже, раціон харчування, що базується на споживанні органічних продуктів, передбачає практично повний захист від подібного роду небезпек, пов'язаних із ймовірним вмістом канцерогенних пестицидів у їжі, яку ми вживаємо. Органічне агровиробництво, виконує за суттю функцією забезпечення людей максимально потенційно безпечною продукцією в масштабах країни. Головним завданням для подальшого розвитку сталих органічних харчових систем $€$ усвідомлення значущості органіку для розвитку економіки та суспільства на всіх рівнях державного управління.

Розвиток органічного сільського господарства також знижує професійний вплив пестицидів на сільськогосподарських працівників та жителів сільської місцевості. Свідченням цього $є$ значне число досліджень щодо вмісту пестицидів в організмах міських та сільських жителів.

Одним із таких досліджень $є$ спільне тайсько-американське дослідження, що проводилося з метою визначення концентрації гліфосату та параквату у материнській та пуповинній крові у 82 вагітних жінок, які народили у трьох провінціях Таїланду.

За допомогою анкет і біологічних зразків, зібраних під час пологів, такі фактори, як особистісні характеристики, професія, участь в аграрних роботах, а також використання гербіцидів в агросфері були оцінені для визначення рівнів вмісту гліфосату та параквату у крові вагітних жінок. Статистичний аналіз здійснювався на основі однофракторної та багатофракторної множинної регресії. У результаті отримали найбільшу кореляцію вмісту параквату або гліфосату з такими фракторами як професія 
та побутові фрактори. Результати переконливо свідчать, що концентрації гліфосату у сироватці крові вагітних жінок при пологах (медіана 17,5, діапазон 0,2-189,1 нг/мл) були значно вищими ( $<<0,007)$, ніж у сироватці пуповинної крові (медіана 0,2, діапазон 0,2-94,9 нг/мл). Однак концентрації параквату у сироватці крові вагітних

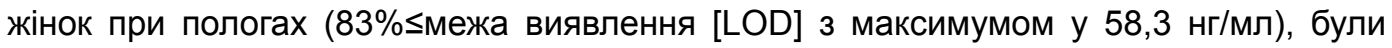
аналогічні концентраціям у сироватці пуповинної крові $(80 \%<$ LOD з максимумом 47,6 нг/мл). Жінки з рівнем гліфосату > LOD у сироватці крові при пологах в $11,9$ разів частіше працювали агрономами ( $<<0,001)$, жили у 3,7 разів частіше поруч 3 сільськогосподарськими районами $(p=0,006)$ і у 5,9 разів частіше мали членів сім'ї, які працювали у сільському господарстві $(p<0,001)$. Єдиним фрактором, який впливав на вміст параквату у крові вагітних жінок при пологах був фрактор трудової діяльності на землі у третьому триместрі вагітності [3, с. 17].

Тобто вагітні жінки, які самі працювали у сільському господарстві або мали членів сім'ї, які були зайняті в агровиробництві, мали більш високий вміст залишків досліджуваних пестицидів у крові.

Отже, залишки пестицидів у продуктах харчування є вагомим джерелом впливу на здоров'я населення, особливо сільського. Це також було продемонстровано у нещодавніх дослідженнях, де було обґрунтовано, що системне споживання фруктів і овочів позитивно корелює із меншою концентрацією пестицидів в організмі [20]. Вміст залишків пестицидів в організмі був помітно знижений вже через тиждень зміни раціону і переходу до споживання органічних продуктів.

Органічні харчові продукти також фрактично не можуть містити генетично модифікованих організмів (ГМО) і штучних добавок. Хоча традиційно вирощені продукти вважаються безпечними, відсутність всіх неприродних інгредієнтів робить органічні продукти без сумніву більш здоровим і безпечним вибором, оскільки довгострокові наслідки умовно «безпечних» доз пестицидів, консервантів та інших хімічних речовин залишаються невідомими.

Питання використання ГМО та різного роду штучних інгредієнтів (синтетичних консервантів, барвників тощо) у харчових продуктах $€$ окремою та дискусійною темою дослідження. Однак численні дослідження свідчать про серйозну небезпеку їх використання при виробництві та споживанні харчової продукції. Міжнародне органічне законодавство, натомість, передбачає заборону використання ГМО, хімічносинтезованих добрив та засобів захисту, інших штучних інгредієнтів в органічному виробництві, що дозволяє фрактично зняти дискусії з цього приводу та вживати натуральні природні продукти, мінімізуючи потенційні ризики для здоров'я та життя людини.

На додаток до прямих переваг для здоров'я, органічні продукти харчування пропонують ряд непрямих, але так само важливих позитивних впливів як на здоров'я людини, так і на навколишнє середовище. Оскільки виробництво органічної їжі суворо забороняє використання небезпечних хімічних речовин, мінімізуються ризики забруднення ґрунту або води, що впливає не лише на населення, що проживає поблизу звичайних фермерських господарств, але й на цілі райони, в межах яких великі вітчизняні агрохолдинги широко практикують інтенсивне агровиробництво. 
Отже, ґрунтуючись на вищевикладеному, можна зробити висновок про потенційні позитивні наслідки для здоров'я від виробництва та вживання органічних харчових продуктів. Однак для подальшої конкретизації даного потенціалу бачиться доречним майбутні дослідження спрямувати за кількома напрямами:

Порівняльні дослідження щодо харчової цінності органічної та конвенційної продукції (такі дослідження потрібні для отримання більш глибокого розуміння зв'язку між практиками вирощування та поживністю харчових продуктів).

Інтервенційні дослідження (для вивчення впливу специфіки харчування або дієти на здоров'я як тварин, так і людей).

Спостережні дослідження (масштабні дослідження на великій вибірці будуть важливими для підтвердження впливу на здоров'я великої кількості населення, зокрема населених пунктів. Не виключено, що такі дослідження можуть показати несподівані результати, які не можуть бути досліджені за допомогою інтервенційних через часові рамки та територіальні особливості).

Висновки та перспективи подальших досліджень. Вищенаведене доволі переконливо свідчить про те, що споживання органічних продуктів може зменшити ризик потрапляння канцерогенів в організм, алергічних захворювань, надлишкової ваги та ожиріння тощо. Крім того, деякі види органічної продукції можуть бути більш поживними та потенційно кориснішими для людини порівняно з конвенційними аналогами.

В органічному сільському господарстві використання синтетичних пестицидів заборонене, а залишки у конвенційних фруктах і овочах є основним джерелом ризику захворюваності у людей. Епідеміологічні дослідження неодноразово повідомляли про несприятливий вплив агрохімікатів на когнітивний розвиток дітей при нинішніх рівнях впливу, але ці дані досі не були використані в офріційних оцінках ризику окремих пестицидів. Вміст поживних речовин відрізняється лише мінімально в органічних та конвенційних культурах, але вміст фенольних сполук в органічних фруктах та овочах помітно вищий. Існує висока ймовірність зниження вмісту кадмію в органічних зернових культурах. Органічні молочні продукти, можливо і м'ясо, мають більш високий вміст омега-3 жирних кислот у порівнянні з конвенційними продуктами. Велике занепокоєння викликає поширене використання антибіотиків при конвенційному вирощуванні тварин, оскільки це є ключовим фрактором стійкості до антибіотиків у населення. Профрілактика захворюваності тварин і фактично невикористання антибіотиків, як це практикується в органічному виробництві, може мінімізувати цей ризик з потенційно значними вигодами для здоров'я населення.

Таким чином, виробництво органічних харчових продуктів має низку задокументованих і потенційних переваг для організму людини, тому швидше за все сприятиме здоров'ю населення і відповідно зростанню ринку споживання такої продукції. Це ще раз підтверджує важливу цільову орієнтацію органічного сільського господарства на забезпечення здоров'я людей, тварин, землі та усього навколишнього середовища, що задекларовано у органічному принципі здоров'я.

\section{Список використаних джерел}

1. Безконтрольне використання пестицидів в Україні // Аналітична записка [Електронний ресурс]. - Режим доступу : http://epl.org.ua/ environment/analitychna-zapyska-bezkontrolne-vykorystannya-pestytsydiv-vukrayini/\#sdfootnote4anc (дата звернення: 08.02.2019р.). 
2. Бубела Т. Безпечність та якість харчової продукції / Т. Бубела, О. Воробець // Вимірювальна техніка та метрологія: міжвідомчий наук.-техн. зб. Національного університету «Львівська політехніка». - Львів: Видавництво Національного ун-ту «Львівська політехніка», 2010. - Вип. - 71. С. 139-144.

3. Гліфросат у крові вагітних селянок // Журнал ORGANIC.UA. - № 06-08(41). 2017. C. 17.

4. Заклади охорони здоров'я та захворюваність населення України у 2017 році: Cтат. збір. Державна служба статистики України [Електронний ресурс]. Режим доступу : http://www.ukrstat.gov.ua/druk/publicat/kat_u/2018/zb/06/zb_ zoz_17.pdf (дата звернення: 28.02.2019р.).

5. КошкалдаІ.В.Актуальніпитанняпродовольчогозабезпечення/I. В. Кошкалда// Вісник Сумського національного аграрного університету, 2017. - Вип. 4. C. 207-212. - (Сер.: «Економіка і менеджмент»).

6. Ооріційний сайт Федерації органічного руху України [Електронний ресурс]. Режим доступу : http://organic.com.ua/uk/homepage/2010-01-26-13-42-29 (dama звернення: 01.03.2019 р.).

7. Сільське господарство України у 2017 р. : cmam. зб. - Державна служба статистики України [Електронний ресурс]. - Режим доступу : http:// www.ukrstat.gov.ua/druk/publicat/kat_u/2018/zb/09/zb_sg2017_pdf.pdf (Dama звернення: 01.03.2019 р.).

8. Терещенко В. К. Розвиток органічного сільського господарства як фрактор прискорення екологізаціїагровиробництва/В. К. Терещенко, Є. В. Милованов// Вісник аграрної науки. - 2018. - № 10(787). - C. 75-83.

9. Abete I., Romaguera D., Vieira A.R., Lopez de Munain A., Norat T. Association between total, processed, red and white meat consumption and all-cause, CVD and IHD mortality: a meta-analysis of cohort studies. Br J Nutr. 2014, 112(5):762-775.

10. Boeing H., Bechthold A., Bub A., Ellinger S., Haller D., Kroke A., Leschik-Bonnet E., Muller M.J., Oberritter H., Schulze M., et al. Critical review: vegetables and fruit in the prevention of chronic diseases. Eur J Nutr. 2012, 51(6):637-663.

11. Dangour, K., Hayter A., Aikenhead, A., Allen, E., Uauy, R. Nutrition-related health effects of organic foods: a systematic review. Am J Clin Nutr. 2010, 92(1):203-210.

12. Eisinger-Watzl M., Wittig F., Heuer T., Hoffmann I. Customers purchasing organic food - do they live healthier? Results of the German National Nutrition Survey II. Eur J Nutr Food Saf. 2015, 5(1):59-71.

13. Fagerstedt S., Hesla H.M., Ekhager E., Rosenlund H., Mie A., Benson L., Scheynius A., Alm J. Anthroposophic lifestyle is associated with a lower incidence of food allergen sensitization in early childhood. J Allergy Clin Immunol. 2016, 137(4):12531256.e1251.

14. Forman J., Silverstein J. Organic foods: health and environmental advantages and disadvantages. Pediatrics. 2012, 130(5):e1406-e1415.

15. Huber M., van de Vijver L. P., Parmentier H., Savelkoul H., Coulier L., Wopereis S., Verheij E., van der Greef J., Nierop D., Hoogenboom R.A. Effects of organically and conventionally produced feed on biomarkers of health in a chicken model. Br J Nutr. 2010, 103(5):663-676. 
16. Human health implications of organic food and organic agriculture // European Parliamentary Research Service. Retrieved from: http://www.europarl.europa.eu/ RegData/etudes/STUD/2016/581922/EPRS_STU(2016)581922_EN.pdf.

17. Hyland C., Bradman A., Gerona R., Patton S., Zakharevich I., Gunier R.B., Klein $K$. Organic diet intervention significantly reduces urinary pesticide levels in U.S. children and adults. Environmental Research. 2019, 171:568-575.

18. IARC Monograph on Glyphosate // The International Agency for Research on Cancer. Retrieved from: https://www.iarc.fr/featured-news/media-centre-iarc-newsglyphosate/.

19. Kesse-Guyot E., Peneau S., Mejean C., Szabo de Edelenyi F., Galan P., Hercberg $S$., Lairon D. Profiles of organic food consumers in a large sample of French adults: results from the Nutrinet-Sante cohort study. PLoS One. 2013, 8(10):e76998.

20. Oates L., Cohen M., Braun L., Schembri A., Taskova R. Reduction in urinary organophosphate pesticide metabolites in adults after a week-long organic diet. Environ Res. 2014,132(0):105-111.

21. Pesticides - Use per area of cropland // FAOSTAT. Retrieved from: http://www.fao. org/faostat/en/\#data/EP/visualize

22. Smith-Spangler C., Brandeau M.L., Hunter G.E., Bavinger J.C., Pearson M., Eschbach P.J., Sundaram V., Liu H., Schirmer P., Stave C., et al. Are organic foods safer or healthier than conventional alternatives?: a systematic review. Ann Intern Med. 2012, 157(5):348-366.

23. Sri Lankan President announces ban on import of glyphosate herbicide//GMWATCH. Retrieved from: https://www.gmwatch.org/en/news/latest-news/16179-sri-lankanpresident-announces-ban-on-import-of-glyphosate-herbicide.

24. Stenius F., Swartz J., Lilja G., Borres M., Bottai M., Pershagen G., Scheynius A., Alm J. Lifestyle factors and sensitization in children - the ALADDIN birth cohort. Allergy. 2011, 66(10):1330-1338.

25. Torjusen H., Brantsaeter A.L., Haugen M., Alexander J., Bakketeig L.S., Lieblein G., Stigum H., Naes T., Swartz J., Holmboe-Ottesen G., et al. Reduced risk of pre-eclampsia with organic vegetable consumption: results from the prospective Norwegian mother and child cohort study. BMJ Open. 2014, 4(9):e006143.

26. Velimirov A., Huber M., Lauridsen C., Rembiałkowska E., Seidel K., Bügel S. Feeding trials in organic food quality and health research. J Sci Food Agric. 2010, 90(2):175-182.

27. Willer H., Lernoud J. The World of Organic Agriculture. Statistics and Emerging trends. FiBL\&IFOAM - Organic International. Germany: Medienhaus Plump, 2019. - 352 p.

\section{Reference}

1. Bezkontrolne vykorystannia pestytsydiv $v$ Ukraini [Uncontrolled use of pesticides], from http://epl.org.ua/environment/analitychna-zapyska-bezkontrolnevykorystannya-pestytsydiv-v-ukrayini/\#sdfootnote4anc [in Ukrainian].

2. Bubela T., Vorobets O. Bezpechnist ta yakist kharchovoi produktsii [Safety and quality of food products]. Vymiriuvalna tekhnika ta metrolohiia - Measuring Equipment and 
Metrology, Lviv: Vydavnytstvo Natsionalnoho un-tu «Lvivska politekhnika», 2010, Issue 71, p. 139-144 [in Ukrainian].

3. Hlifosat u krovi vahitnykh selianok [Glyphosate in the blood of rural pregnant women]. Organic. UA, 2017, No. 06-08(41), p. 17 [in Ukrainian].

4. Zaklady okhorony zdorov'ia ta zakhvoriuvanist naselennia Ukrainy u 2017 rotsi: Stat. zbir. Derzhavna sluzhba statystyky Ukrainy [Healthcare facilities and morbidity rates in Ukraine, 2017: Statistical book. State Statistics Service of Ukraine], from http:// www.ukrstat.gov.ua/druk/publicat/kat_u/2018/zb/06/zb_zoz_17.pdf [in Ukrainian].

5. Koshkalda I. V. Aktualni pytannia prodovolchoho zabezpechennia [Current issues of provision of food supplies]. Visnyk Sumskoho natsionalnoho ahrarnoho universytetu. Ser.: Ekonomika i menedzhment - Bulletin of Sumy National Agrarian University. Series: Economy and Management, 2017, Issue 4, p. 207-212 [in Ukrainian].

6. OfitsiinyisaitFederatsiiorhanichnohorukhuUkrainy[FederationofOrganicMovement, official site], from http://organic.com.ua/uk/homepage/2010-01-26-13-42-29 [in Ukrainian].

7. Silske hospodarstvo Ukrainy u 2017 r.: stat. zb. Derzhavna sluzhba statystyky Ukrainy [Agriculture of Ukraine in 2017: Statistical book. State Statistics Service of Ukraine], from http://www.ukrstat.gov.ua/druk/publicat/kat_u/2018/zb/09/zb_ sg2017_pdf [in Ukrainian].

8. Tereshchenko V. K., Mylovanov Ye. V. Rozvytok orhanichnoho silskoho hospodarstva yak faktor pryskorennia ekolohizatsii ahrovyrobnytstva [The development of oorganic agriculture as a factor environmentalization of agricultural production]. Visnyk ahrarnoi nauky - Bulletin of Agricultural Science, 2018, No. 10(787), p. 75-83 [in Ukrainian].

9. Abete I., Romaguera D., Vieira A.R., Lopez de Munain A., Norat T. Association between total, processed, red and white meat consumption and all-cause, CVD and IHD mortality: a meta-analysis of cohort studies. British Journal of Nutrition, 2014, No. 112(5), p. 762-775 [in English].

10. Boeing H., Bechthold A., Bub A., Ellinger S., Haller D., Kroke A., Leschik-Bonnet E., Muller M.J., Oberritter H., Schulze M., et al. Critical review: vegetables and fruit in the prevention of chronic diseases. European Journal of Nutrition, 2012, No. 51(6), p. 637-663 [in English].

11. Dangour K., Hayter A., Aikenhead A., Allen E., Uauy R. Nutrition-related health effects of organic foods: a systematic review. The American Journal of Clinical Nutrition, 2010, No. 92(1), p. 203-210 [in English].

12. Eisinger-Watzl M., Wittig F., Heuer T., Hoffmann I. Customers purchasing organic food - do they live healthier? Results of the German National Nutrition Survey II. European Journal of Nutrition and Food Safety, 2015, No. 5(1), p. 59-71 [in English].

13. Fagerstedt S., Hesla H.M., Ekhager E., Rosenlund H., Mie A., Benson L., Scheynius A., Alm J. Anthroposophic lifestyle is associated with a lower incidence of food allergen sensitization in early childhood. Journal of Allergy and Clinical Immunology, 2016, No. 137(4), p. 1253-1256 [in English].

14. Forman J., Silverstein J. Organic foods: health and environmental advantages and disadvantages. Pediatrics, 2012, No. 130(5), p. e1406-e1415 [in English]. 
15. Huber M., van de Vijver L. P., Parmentier H., Savelkoul H., Coulier L., Wopereis S., Verheij E., van der Greef J., Nierop D., Hoogenboom R. A. Effects of organically and conventionally produced feed on biomarkers of health in a chicken model. British Journal of Nutrition, 2010, No. 103(5), p. 663-676 [in English].

16. Human health implications of organic food and organic agriculture. European Parliamentary Research Service, from http://www.europarl.europa.eu/RegData/ etudes/STUD/2016/581922/EPRS_STU(2016)581922_EN.pdf [in English].

17. Hyland C., Bradman A., Gerona R., Patton S., Zakharevich I., Gunier R.B., Klein K. Organic diet intervention significantly reduces urinary pesticide levels in U.S. children and adults. Environmental Research. 2019, No. 171, p. 568-575 [in English].

18. IARC Monograph on Glyphosate. The International Agency for Research on Cancer, from https://www.iarc.fr/featured-news/media-centre-iarc-news-glyphosate/ [in English].

19. Kesse-Guyot E., Peneau S., Mejean C., Szabo de Edelenyi F., Galan P., Hercberg S., Lairon D. Profiles of organic food consumers in a large sample of French adults: results from the Nutrinet-Sante cohort study. PLoS One, 2013, No. 8(10), p. e76998 [in English].

20. Oates L., Cohen M., Braun L., Schembri A., Taskova R. Reduction in urinary organophosphate pesticide metabolites in adults after a week-long organic diet. Environmental Research, 2014, No. 132(0), p. 105-111 [in English].

21. Pesticides - Use per area of cropland. FAOSTAT, from http://www.fao.org/faostat/ en/\#data/EP/visualize [in English].

22. Smith-Spangler C., Brandeau M.L., Hunter G.E,. Bavinger J.C., Pearson M., Eschbach P.J., Sundaram V., Liu H., Schirmer P., Stave C., et al. Are organic foods safer or healthier than conventional alternatives?: a systematic review. An International Medicine, 2012, No. 157(5), p. 348-366 [in English].

23. Sri Lankan President announces ban on import of glyphosate herbicide. GMWATCH, from https://www.gmwatch.org/en/news/latest-news/16179-sri-lankan-presidentannounces-ban-on-import-of-glyphosate-herbicide [in English].

24. Stenius F., Swartz J., Lilja G., Borres M., Bottai M., Pershagen G., Scheynius A., Alm J. Lifestyle factors and sensitization in children - the ALADDIN birth cohort. Allergy, 2011, No. 66(10), p. 1330-1338 [in English].

25. Torjusen H., Brantsaeter A.L., Haugen M., Alexander J., Bakketeig L.S., Lieblein G., Stigum H., Naes T., Swartz J., Holmboe-Ottesen G., et al. Reduced risk of preeclampsia with organic vegetable consumption: results from the prospective Norwegian mother and child cohort study. BMJ Open, 2014, No. 4(9), p. e006143 [in English].

26. Velimirov A., Huber M., Lauridsen C., Rembiałkowska E., Seidel K., Bügel S. Feeding trials in organic food quality and health research. The Journal of the Science of Food and Agriculture, 2010, No. 90(2), p. 175-182 [in English].

27. Willer H., Lernoud J. The World of Organic Agriculture. Statistics and Emerging trends. FiBL\&IFOAM - Organic International. Germany: Medienhaus Plump, 2019, 352 p. [in English].

Редакція отримала матеріал 24 грудня 2018 р. 